\title{
MODEL LITERASI MEDIA DENGAN MENGGUNAKAN MULTIMEDIA INTERAKTIF BERBASIS KEARIFAN LOKAL MASYARAKAT SALATIGA
}

\author{
Rini Darmastuti ${ }^{1}$, Sri Winarso Martyas Edi ${ }^{2}$, Erwien Christianto ${ }^{3}$ \\ Universitas Kristen Satya Wacana \\ J1. Diponegoro 52-60 Salatiga, Indonesia, 50711, Telp. (0298) 321212 \\ Email : Rini.darmastuti@staff.uksw.edu'1, winarso@staff.uksw.edu², \\ erwien.christanto@staff.uksw.edu ${ }^{3}$
}

\begin{abstract}
The purpose of this research is to know a model literacy a medium for elementary school students by the use of the interactive multimedia-based wisdom of the local community, Salatiga. Methods used in this research is qualitative and approach ethnography communication. The data collection was done through observation and in-depth interviews with cultural and teachers primary schools in Salatiga. The results show that 1). The Local wisdom of Salatiga community has been applied in forms of appreciation, cooperation and tolerance based on the teachings of Raden Mas Said. 2). This local wisdom can be used as a basis for media literacy 3). There are two models of literacy media based on local knowledge, i.e., in the form of informal communication done by teachers and parents, and in the form of education through games. The Game with Salatiga City setting and with figures of Wales and Asia as symbols of that tolerance is the local wisdom of Salatiga community which will be used as learning media in schools. This research contributes to provide media literacy model using interactive multimedia based on local wisdom of the community in Salatiga.
\end{abstract}

Keywords: Media Literacy Model, elementary school students, Local wisdom, Interactive Multimedia, Salatiga

\begin{abstract}
Abstrak
Tujuan penelitian ini adalah mengetahui model literasi media untuk anak-anak sekolah dasar dengan menggunakan multimedia interaktif berbasis kearifan lokal masyarakat Salatiga. Metode yang digunakan dalam penelitian ini adalah kualitatif dan pendekatan etnografi komunikasi. Pengumpulan data dilakukan melalui observasi dan wawancara mendalam dengan budayawan dan guru-guru Sekolah Dasar di Salatiga. Hasil dari penelitian ini adalah 1). Kearifan lokal masyarakat Salatiga teraplikasi dalam bentuk menghargai, gotong royong dan toleransi yang didasarkan pada ajaran Raden Mas Said. 2). Kearifan lokal ini dapat digunakan sebagai dasar literasi media 3). Ada dua model literasi media yang dihasilkan dalam penelitian ini, yaitu model literasi dalam bentuk komunikasi secara informal dan model literasi dalam bentuk edukasi melalui game. Model literasi dalam bentuk komunikasi informal dilakukan oleh guru dan oorang tua. Model literasi dalam bentuk game dibuat dengan setting kota Salatiga dengan tokoh Welas dan Asih sebagai simbol dari toleransi yang merupakan kearifan lokal masyarakat Salatiga, sebagai media pembelajaran di sekolah-sekolah. Kontribusi penelitian ini adalah penemuan model literasi media dengan menggunakan multimedia interaktif berbasis kearifan lokal masyarakat Salatiga.
\end{abstract}

Kata kunci : Model Literasi Media, Anak-Anak SD, Kearifan Lokal, Multimedia Interaktif, Salatiga

\section{Pendahuluan}

Nasib naas menimpa Has, bocah kelas 1 SD Yayasan Islam Zaidar Yahya. Ia dikeroyok oleh lima temannya di sekolah yang menirukan adegan di Sinetron 7 Manusia Harimau yang tayang di televisi swasta nasional. Has akhirnya mengembuskan nafas terakhir pada hari Selasa, 28 april 2015 pada malam hari sekitar pukul 22.00 WIB. Kejadian serupa juga dialami A, salah satu murid Sekolah Dasar 
di Kabupaten Bandung, Jawa Barat. Pada tanggal 18 September 2015, siswa kelas tiga ini meregang nyawanya usai dipukul teman sekelasnya di dalam salah satu ruang kelas di sekolah tersebut.

Tindakan yang dilakukan oleh temantemannya ini sebetulnya merupakan bentuk tindakan meniru program tayangan tarung bebas fiktif bernama Smackdown yang disiarkan secara rutin di salah satu stasiun swasta Indonesia. Kejadian yang menimpa A ini hampir mirip dengan kejadian yang menyebabkan kematian RZ yang meninggal dunia akibat di-smackdown kakak kelasnya pada 2006 silam. Kejadian ini terulang lagi setelah 9 tahun kasus itu berlalu (Sumber : http://nasional.news.viva.co.id/news/read/ 679519-anak-anak-yang-meregang-nyawaakibat-tayangan-televisi, akses 29 Mei 2016).

Dua kejadian ini hanyalah sebagian kecil dari 'tragedi' yang terjadi sebagai akibat dari pengaruh televisi terhadap sikap dan perilaku penonton televisi yang ada di negeri ini. Hal ini terjadi karena televisi sudah menjadi bagian yang tidak dapat dipisahkan dalam kehidupan setiap orang. Dari bangun tidur hingga menjelang tidur, masyarakat kita mendapat terpaan dari televisi dengan sangat luar biasa. Berdasarkan survey Nielsen Consumer Media View (2017) yang dilakukan di 11 kota di Indonesia, penetrasi Televisi masih memimpin dengan 96 persen disusul dengan Media Luar Ruang (53\%), Internet (44\%), Radio (37\%), Koran (7\%), Tabloid dan Majalah (3\%). Berdasarkan survei Nielsen Cross-Platform 2017, saat ini ada beragam cara yang dilakukan untuk mengakses konten TV atau film. TV terrestrial dan TV kabel masih menjadi pilihan utama dengan perolehan 77 persen (Sumber : http://www. nielsen.com/id/en/press-room/2017/TrenBaru-di-Kalangan-Pengguna-Internet-diIndonesia.html. akses 20 Nopember 2017).

Hasil penelitian di atas menunjukkan bahwa televisi menjadi media favorit bagi masyarakat kita. Televisi mempunyai peran yang sangat besar dalam membentuk masyarakat Indonesia. Padahal kalau kita lihat dalam kehidupan sehari-hari, konsumen terbesar untuk tayangan televisi ini adalah anak-anak, tidak terkecuali untuk anak-anak di Salatiga. Berdasarkan penelitian yang dilakukan oleh penulis pada bulan april 2016 yang dilakukan di 3 Sekolah Dasar Negeri dan 2 Sekolah Dasar Swasta yang ada di Salatiga, anak-anak Sekolah Dasar yang ada di Salatiga ini setiap hari menonton televisi lebih dari 3 jam. Jumlah ini bukanlah jumlah yang sedikit.

Fenomena yang terjadi di masyarakat ini merupakan sebuah urgensi dan perlu penanganan yang serius. Dibutuhkan satu strategi yang tepat untuk melakukan literasi media, salah satunya adalah dengan menggunakan kearifan lokal. Ada beberapa penelitian yang sudah dilakukan dengan menekankan kearifan lokal sebagai dasar dalam membuat strategi literasi media. Pada tahun 2014 dan 2015, Mario Antonius Birowo dan Rini Darmastuti melakukan penelitian dengan judul "Strategi Literasi Media pada Remaja Yogyakarta dengan Berbasis Kearifan Lokal Masyarakat Yogyakarta”. Hasil penelitian ini menjelaskan bahwa strategi literasi media dilakukan 
melalui pengajaran seni rupa, seni tari dan seni musik. Literasi media melalui kearifan lokal masyarakat Yogyakarta ini digunakan sebagai strategi untuk membangun remaja yang cerdas dalam menggunakan media melalui dua cara, yaitu pemahaman terhadap budaya dan menggunakan waktu mereka secara efektif melalui budaya (Birowo, 2015: 63).

Penelitian lainnya dilakukan oleh Jusuf Tjahjo Purnomo dan Rini Darmastuti pada tahun 2016 dengan judul "Model Literasi Media dalam Konsep Kearifan Lokal Masyarakat Samin". Penelitian ini berusaha untuk menggali kearifan lokal yang dimiliki oleh masyarakat Samin dalam menghadapi terpaan televisi. Sebagai masyarakat Adat yang sangat taat dan menghidupi budaya yang diajarkan oleh nenek moyang mereka, masyarakat Samin tidak terpengaruh oleh pesan-pesan dan ajaran yang disampaikan melalui televisi. Kearifan lokal yang mereka miliki menjadi tameng dalam menghadapi terpaan media televisi ini (Purnomo dan Darmastuti, 2016: 33).

Kedua penelitian diatas menunjukkan bahwa kearifan lokal menjadi kekuatan dalam membangun kecerdasan dalam menggunakan media. Literasi media dilakukan dengan berdasarkan pada kearifan lokal yang dimiliki oleh setiap masyarakat. Topik yang dibahas dalam tulisan ini merupakan kelanjutan dan pembahasan lebih mendalam dari kedua hasil penelitian yang dilakukan di Yogyakarta dan di Sukolilo. Fokus pembahasan dalam tulisan ini agak berbeda dengan pembahasan dari kedua hasil penelitian sebelumnnya. Tulisan ini lebih membahas model literasi media melalui multimedia interaktif dengan berdasarkan kearifan lokal masyarakat Salatiga. Multimedia interaktif yang ditemukan dalam penelitian ini adalah multimedia interaktif dalam bentuk game, sebagai media edukasi.

Melek media atau "media literacy" adalah sebuah alternatif yang bertujuan untuk memberdayakan publik di tengah kepungan media. Konsep ini memiliki tujuan untuk mendidik publik supaya mampu berinteraksi dan memanfaatkan media secara cerdas dan kritis, sehingga publik tidak mudah dibodohi media dan tidak mudah dieksploitasi media untuk kepentingan-kepentingan yang tidak berpihak pada kebutuhan publik. Tindakan konkret melek media adalah pendidikan dan pelatihan bagi publik supaya mampu memahami isi media, mampu mengakses dan menggunakan media, serta mampu berkomunikasi melalui media secara interaktif.

David Considine (dalam The Journal of Media Literacy, Volume 41, Number 2) memberikan definisi media literacy sebagai "The ability to access, analyze, evaluate and communicate information in a variety of format including print and nonprint" Dalam pandangan David Considine, masyarakat yang sudah mengalami Media Literacy atau masyarakat yang sudah melek media, adalah masyarakat yang memiliki kemampuan untuk mengakses, menganalisis, mengevaluasi dan mengkomunikasikan informasi dalam berbagai format pesan yang disampaikan oleh media massa, baik itu cetak maupun elektronik.

W. James Potter (1998 : 5), mendefinisikan literasi media dengan definisi "Media Literacy is a perspective from which we expose ourselves to the media and interpret the meanings of the messages we encounter". 
Menurut Potter, literasi media merupakan sebuah perspektif di mana kita dapat secara aktif menunjukkan kemampuan kita kepada media untuk menginterpretasikan makna dari pesan yang kita temui. Secara sederhana, literasi media merupakan kemampuan menyaring, memilah, dan memilih pesanpesan yang terdapat dalam media, baik cetak maupun elektronik.

Potter menjelaskan literasi media melalui model yang dia buat. Ada empat faktor yang digunakan pada model literasi media ini, yaitu struktur pengetahuan, lokus personal, kompetensi dan keterampilan, serta arus tugas pengolahan informasi. Potter mengatakan, "The foundation of building media literacy is a set of five strong knowledge structures. The foundational knowledge structures are media effects, media content, media industries, the real world, and the self" (Potter, 2004: 33). Model literasi media yang dijelaskan oleh Potter ini sering disebut dengan 'The Cognitive Model of Media Literacy', seperti dalam gambar dibawah ini:
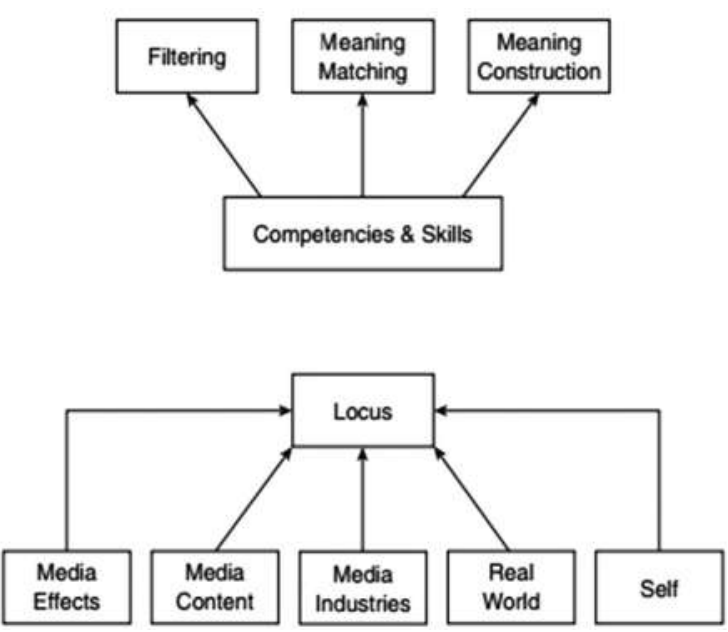

Gambar 1. The Cognitive Model of Media Literacy

(Sumber : Potter, 2004)
Douglas Kellner (2010: 3) dalam bukunya "Budaya Media: Cultural Studies, Identitas dan Politik, antara Modern dan Postmoder" mengatakan bahwa masyarakat sebetulnya dapat menolak pengaruh-pengaruh budaya media dengan menggunakan budaya yang mereka miliki. Pesan-pesan dominan yang disampaikan oleh media massa dan penciptaan pembacaan serta pemanfaatan pribadi terhadap budaya yang diproduksi secara masal oleh media dapat difilter dengan menggunakan budaya yang dimiliki oleh masyarakat sebagai sumber pemberdayaan diri mereka dan menciptakan makna identitas dan bentuk kehidupan mereka sendiri. Menurut Kellner, ada satu cara yang dapat digunakan untuk menciptakan masyarakat yang cerdas dalam menggunakan media atau masyarakat yang melek media, yaitu dengan menggunakan budaya mereka sendiri.

Kearifan lokal yang merupakan manifestasi dari ajaran-ajaran budaya yang dihidupi oleh suatu masyarakat lokal, dapat digunakan sebagai filter untuk menyerap dan mengolah kebudayaan asing sesuai watak dan kemampuan sendiri. Budaya asing disini termasuk budaya-budaya asing yang terpublikasi ke masyarakat melalui media massa. Nilai-nilai budaya serta kearifan lokal yang dimiliki oleh masyarakat dapat digunakan sebagai dasar pada saat menginterpretasikan pengalaman yang mereka peroleh dari media massa, sehingga tingkah laku sosial yang terbentuk merupakan tingkah laku sosial yang sesuai dengan budaya masyarakat itu bukan tingkah laku sosial yang berdasarkan budaya media. 
Tujuan dari penelitian ini adalah untuk mengetahui model literasi media untuk anakanak sekolah dasar dengan menggunakan multimedia interaktif berbasis kearifan lokal masyarakat Salatiga.

\section{Metode Penelitian}

Tulisan ini merupakan hasil dari penelitian yang dilakukan pada tahun 2017 dengan judul "Model literasi media untuk anak-anak Sekolah Dasar dengan menggunakan Multimedia Interaktif dalam konsep kearifan lokal masyarakat Salatiga". Penelitian yang dibiayai oleh Ristekdikti dalam skema penelitian produk terapan ini dilakukan di Salatiga pada tahun 2017. Penelitian ini menggunakan metode kualitatif dan pendekatan etnografi komunikasi untuk menggali kearifan lokal masyarakat Salatiga dan membuat model literasi media berdasarkan kearifan lokal masyarakat Salatiga.

Data dalam penelitian ini diperoleh melalui observasi secara langsung serta wawancara mendalam. Observasi dilakukan di kota Salatiga untuk menggali kekayaan budaya dan kearifan lokal masyarakat Salatiga. Wawancara mendalam dilakukan dengan budayawan, guru serta tokoh-tokoh masyarakat Salatiga, sebagai orang kunci dalam penelitian ini. Setelah melakukan observasi dan wawancara mendalam, peneliti kemudian mengkonstruksi pesanpesan yang didapat dari narasumber. Setelah menggali kearifan lokal masyarakat Salatiga, peneliti kemudian memetakan kearifan lokal masyarakat Salatiga yang selama ini digunakan sebagai filter dalam mengadapi terpaan pesan yang berasal dari televisi dan membuat model literasi media.

\section{Hasil Penelitian dan Pembahasan}

Tulisan dengan judul "Model Literasi Media untuk Anak-Anak Sekolah Dasar dengan menggunakan Multimedia Interaktif Berbasis Kearifan Lokal Masyarakat Salatiga" ini merupakan hasil penelitian yang dilakukan dengan menggunakan metode kualitatif dan pendekatan etnografi komunikasi. Berdasarkan pada pemahaman bahwa etnografi merupakan studi tentang individuindividu yang diamati dalam kondisi yang netral dan alami, maka penulis melakukan pengamatan dalam kehidupan masyarakat Salatiga melalui kegiatan yang mereka lakukan dalam kehidupan sehari-hari.

Penulis melakukan observasi secara langsung dengan melihat dan mengamati kegiatan yang dilakukan oleh masyarakat Salatiga sehari-hari untuk memahami kearifan lokal yang dimiliki oleh masyarakat Salatiga. Sebagai penelitian etnografi, penulis melakukan pengamatan terhadap budaya dan kearifan lokal masyarakat Salatiga selama 2 tahun terakhir dan ditambah dengan pengamatan penulis sejak tinggal di kota Salatiga pada tahun 1994. Dari pengamatan yang penulis lakukan, penulis menemukan sikap dan kebiasaan hidup masyarakat Salatiga yang saling bekerjasama, menghargai, menghormati dan toleransi. Sikap dan kebiasaan yang merupakan wujud kearifan lokal yang dimiliki oleh masyarakat Salatiga, yang sudah mulai jarang dimiliki oleh masyarakat lainnya.

Berdasarkan pengamatan penulis, setiap tahun masyarakat Salatiga mempunyai ritual tahunan yang digelar di lapangan Pancasila. Ritual ini merupakan ritual 
yang dilakukan oleh umat Muslim dan umat Kristiani ketika merayakan hari besar agama mereka. Pada saat umat Kristiani mengadakan ibadah Natal maupun Paskah di lapangan Pancasila, umat muslim serta jamaah Masjid yang ada di sekitar lapangan Pancasila yang ikut membantu menjaga pengamanan dan menjaga kendaraan jemaat yang hadir. Kebaktian yang sudah dilakukan sejak tahun 1970 itu tidak pernah menimbulkan masalah. Padahal kebaktian ini diadakan di depan Masjid Raya Darul Amal yang terletak satu kompleks dengan IAIN. Begitu juga sebaliknya, pada saat umat Muslim mengadakan sholat Ied di lapangan Pancasila untuk memperingati hari raya Idhul Fitri serta hari raya Idhul Adha, umat Kristiani yang ikut menjaga keamanan jalannya ibadah dan menjaga kendaraan mereka.

Pada wawancara mendalam yang dilakukan pada tanggal 21 Juli 2017 ini, bapak Jarwadi menjelaskan bahwa budaya masyarakat Salatiga itu dilandasi oleh budaya Hindu. Pendapat ini didasari oleh beberapa tulisan yang didapat dalam prasasti Plumpungan. "Budaya masyarakat Salatiga cenderung mengikut budaya Solo, dengan toleransi dan gotong royong sebagai kearifan Lokal yang dimiliki oleh Masyarakat Salatiga" (Bapak Jawardi, wawancara 21 Juli 2017).

Toleransi dan gotong royong yang merupakan turunan dari ajaran Pangeran Samber Nyowo (Mangkunegoro) kemudian menjadi dasar dari budaya yang berkembang di Salatiga. Salah satu budaya yang berkembang di Salatiga adalah budaya Saparan yang berkembang dibeberapa daerah, yaitu di daerah Randu Acir, di Tegalrejo dan dibeberapa daerah lainnya yang ada di Salatiga.

Pak Jawardi juga menjelaskan perbedaan budaya saparan yang dilakukan di daerah Randu Acir dan daerah Tegalrejo.

"Budaya Saparan di daerah Randu Acir dilakukan dengan menggelar pentas Wayang $\mathrm{Ku}-$ lit. Kearifan lokal dari budaya Saparan yang dilakukan oleh masyarakat Randu Acir ini adalah gotong royong, saling menghargai, patuh pada leluhur (wewaler) dan patuh pada orang tua. Di daerah Tegalrejo, budaya aparan yang dilakukan berbeda dengan saparan yang dilakukan di daerah Randu Acir. Ketika melakukan budaya Saparan, masyarakat yang ada di Tegalrejo melakukan bersih desa, bersih masjid dan bersih-bersih daerah lingkungan sekitar mereka. Kearifan lokal dari budaya Saparan yang dilakukan oleh masyarakat Tegalrejo ini adalah gotong royong dalam membersihkan desa dan tempat ibadah. Gotong royong yang dilakukan oleh masyarakat membentuk kebersamaan dan saling pengertian" (Bapak Jawardi, wawancara 21 Juli 2017).

Narasumber lain yang menjadi sumber informasi dalam tulisan ini adalah Bapak Amrih, budayawan Salatiga sekaligus guru di Sekolah Dasar Laboratorium UKSW. Dalam wawancara mendalam pada tanggal 19 Juli 2017 ini, bapak Amrih mengatakan,

"Budaya Salatiga merupakan akulturasi dari beberapa budaya yang ada, khususnya dari budaya Solo dan Yogyakarta. Pengaruh pangeran Samber Nyowo sangat kuat dalam budaya Salatiga. Pangeran Samber Nyowo memberikan ajaran tentang semangat perjuangan dan falsafah hidup mengenai kemandirian, kebebasan dan kebersamaan" (Bapak Amrih, wawancara 19 Juli 2017).

Pernyataan bapak Amrih ini seperti yang tertulis dalam buku "Pangeran Sambernyowo : ringkasan Sejarah Perjuangan", pangeran Sambernyowo yang pada masa kecilnya terkenal dengan nama Raden Mas Said pernah mengalami masa pembuangan oleh Belanda ke Srilangka (Ceylon). Kondisi inilah yang membuat Raden Mas Said hidup merakyat 
dan sangat dekat dengan rakyat kecil. Sebagai orang Jawa yang hidup taat dengan budaya Jawa, Raden Mas Said mempunyai kepercayaan, "Kebatinan pracaya ing widhi, kelairan pracaya ing bala", yang artinya adalah dalam batinnya percaya Tuhan yang Maha Esa, kelahiran percaya kepada kekuatan wadyabala (Yayasan Mangadeg, 1988 : 8).

Selama masa berperang melawan Belanda, Raden mas Said memiliki prinsip dengan selogan juangnya "Tiji-Tibeh". Tiji Tibeh memiliki dua makna, yaitu mati siji mati kabeh dan mukti siji mukti kabeh. Prinsip ini memiliki makna apabila satu meninggal, maka yang lain akan meninggal. Jika yang satu bahagia, maka yang lain juga akan bahagia, sejahtera satu maka sejahtera semua. Slogan ini menjadi pengikat tali batin antara Gusti (pimpinan) dan kawula (rakyat). Mereka luluh menjadi satu dalam kata dan perbuatan, maju dalam langkah dan derap yang serasi, mereka merupakan keluarga besar yang bagaikan kata pepatah "serumpun bagai serai, seliang bagai tebu", memiliki makna, bersatu hati dalam segala hal (Yayasan Mangadeg, 1988: 21).

Pada perkembangannya prinsip ini menjadi dasar kearifan lokal masyarakat Salatiga. Hal ini terlihat dari penghayatan dan pemahaman para sesepuh dan pinisepuh yang sangat menghidupi ajaran Raden mas Said "mikul duwur mendem jero" serta falsafah "Tri Dharma". inilah yang menjadi dasar dalam budaya Salatiga.

Kearifan lokal masyarakat Salatiga dalam bentuk kebersamaan, saling menghargai dan toleransi yang tinggi, juga teraplikasi dalam konser besar bertajuk Lintas
Agama yang diadakan oleh komunitas lintas Iman Sobat muda dari kampung Percik dengan tema "Aku, Kau Indonesia Kita' pada tanggal 23 Januari 2016. Konser ini bertempat di Institut Agama Islam Negeri (IAIN) Salatiga. Konser ini melibatkan komunitas-komunitas lintas iman di Salatiga dan sekitarnya seperti Sekolah Tinggi Agama Budha Syailendra, Pondok Pesantren Edi Mancoro, GKI Salatiga, PHDI (Parisada Hindu Dharma Indonesia), Pemuda Desa Pulihan, Jama'ah Ahmadiyah Indonesia, GKJ Sidomukti dan PMII. Dalam konser ini sangat nampak kebersamaan dan kerjasama. Konser ini merupakan wujud dari toleransi beragama yang ada di Salatiga.

Terkait dengan strategi literasi media, dalam penelitian yang digunakan dasar dalam tulisan ini, penulis melakukan wawancara mendalam dengan kepala sekolah dan guru-guru Sekolah Dasar yang ada di kota Salatiga. Bu Padmi, salah satu guru di Sekolah Dasar Negeri 2 Salatiga, dalam wawancara mendalam yang dilakukan pada tanggal 23 April 2017 mengatakan bahwa strategi literasi media kepada siswa adalah dengan pendampingan dari guru-guru melalui komunikasi formal dan nor formal.

"Salah satu dampak yang muncul dari terpaan televisi kepada murid-murid adalah terkait dengan konsentrasi. Karena terlalu banyak mengkonsumsi televisi, beberapa murid yang ada di Sekolah ini menjadi sukar untuk berkonsentrasi dan susah diajak untuk berpikir. Oleh karena itu, guru tidak boleh berhenti untuk mengingatkan secara lisan supaya anak-anak tidak terlalu sering menonton televisi. Mengingatkannya bisa di dalam kelas waktu pelajaran maupun pada saat istirahat dengan cara menasehati anak" $(\mathrm{Bu}$ Padmi, wawancara 23 April 2017).

Bu Bangun yang merupakan Kepala Sekolah di Sekolah Dasar Negeri 9 mengatakan perlu 
adanya pemahaman penggunaan televisi secara benar oleh orang tua.

"Supaya anak-anak mempunyai pemahaman dan kesadaran dalam menggunakan televisi, perlu ada edukasi di kelas. Edukasi bisa dilakukan dengan menggunakan video maupun dengan memberikan contoh-contoh yang ada. Selain edukasi kepada siswa di kelas, orang tua juga perlu diberikan pemahaman tentang penggunaan televisi secara benar" (Bu Bangun, wawancara 16 Mei 2017).

Berdasarkan pernyataan ini, maka dalam wawancara mendalam pada tanggal 16 Mei 2017 ini, bu Bangun akhirnya justru meminta kepada penulis untuk memberikan materi tentang literasi media kepada orang tua murid dan kepada siswa-siswi di Sekolah Dasar Negeri 9.

Pak Amrih, guru Sekolah Dasar Laboratorium UKSW serta budayawan salatiga memiliki pendapat yang agak berbeda dengan pendapat bu Padmi dan bu Bangun. Pada wawancara mendalam pada tanggal 2 Juni 2017, pak Amrih mengatakan,

"Untuk mengingatkan dan menyadarkan anakanak dalam menggunakan televisi, perlu ada media yang digunakan. Misalnya seperti yang saya lakukan pada saat ini. Untuk mengingatkan anak-anak tentang budaya Salatiga, saya membuat buku cerita tentang budaya Salatiga. Tujuannya supaya anak-anak tahu dan tidak melupakan budaya Salatiga. Begitu juga untuk televisi. Kita bisa menggunakan buku cerita atau komik untuk mengingatkan anak-anak supaya menonton televisi secara benar" (Pak Amrih, wawancara 2 Juni 2017).

Literasi media merupakan sebuah alternatif untuk memberdayakan masyarakat dari kepungan media. Literasi media memiliki tujuan supaya masyarakat memiliki kemampuan untuk memilih dan memilah pesan-pesan yang disampaikan oleh media. Konsep ini memiliki tujuan untuk mendidik publik supaya mampu berinteraksi dan memanfaatkan media secara cerdas dan kritis.
Akibatnya, publik tidak mudah dibodohi media dan tidak mudah dieksploitasi media untuk kepentingan-kepentingan yang tidak berpihak pada kebutuhan publik. Tindakan konkret melek media adalah pendidikan dan pelatihan bagi publik supaya mampu memahami isi media, mampu mengakses dan menggunakan media, serta mampu berkomunikasi melalui media secara interaktif.

Pada saat ini, literasi media merupakan keahlian yang harus dimiliki oleh setiap orang ditengah gempuran informasi yang tidak bisa dibendung lagi, baik dari media elektronik maupun dari media digital. Banjir informasi yang tidak dapat dibendung, membuat setiap orang harus bijaksana dalam memilih pesan-pesan yang akan dikonsumsi. Di tengah gempuran infomasi ini, bisa dipastikan seorang individu tidak akan bisa bertahan apabila tidak memiliki kemampuan untuk menerima dan mengelola informasi secara bijaksana. Hal inilah yang menjadi kekuatiran untuk anak-anak Sekolah Dasar, khususnya yang ada di Salatiga.

Kekhawatiran ini muncul karena tidak semua anak-anak Sekolah Dasar memiliki kemampuan untuk menerima dan mengelola informasi secara bijaksana. Tidak semua anak Sekolah Dasar merupakan khalayak aktif yang memiliki kemampuan untuk menerima dan mengelola informasi secara bijaksana. Frank Biocca (1988) membedakan audience atau khalayak menjadi khalayak aktif dan pasif. Beberapa karakteristik yang dimiliki oleh khalayak aktif adalah: Pertama, khalayak aktif dianggap selektifketikamengkonsunmsimedia yang akan digunakan. Kedua, utilitarianisme 
(utilitarianism), audience dianggap aktif apabila ketika mengkonsumsi suatu media selalu dilatarbelakangi kepentingan dan tujuan. Mereka mengkonsumsi media untuk memenuhi kepentingan serta kebutuhan yang mereka miliki. Karakteristik yang ketiga adalah intensionalitas (intentionality), yaitu menggunakan secara sengaja. Audience aktif ketika mengkonsumsi suatu media tidak hanya 'sekedar' menonton saja, tetapi dalam setiap aktifitas menonton yang mereka lakukan selalu dilakukan secara sengaja. Keempat, keikutsertaan (involvement), yaitu alasan yang selalu menyertai ketika mereka mengkonsumsi media. Kelima, khalayak aktif dianggap sebagai khalayak yang tidak mudah terpengaruh dan tidak mudah dibujuk oleh rayuan media (Littlejohn \& Gray, 2001, p. 333). Kemudian, yang dimaksud dengan audience pasif adalah audience yang tidak dapat membedakan mana informasi yang layak dan patut di konsumsi, mana yang tidak.

Berdasarkan pengelompokan yang dilakukan oleh Frank Biocca ini, anak-anak Sekolah Dasar sebagian besar bisa dikelompokkan ke dalam audience yang pasif. Oleh karena itu literasi media merupakan urgensi bagi generasi muda ini. Menurut Nina Armando (2010), ada tiga manfaat dari literasi media untuk generasi muda ini, yaitu pertama membantu anak belajar berpikir, merenung dan meraih pengetahuan baru serta menghubunghubungkan berbagai gagasan. Kedua, melatih anak untuk berpikir kritis, dan ketiga membantu anak untuk menikmati kegiatan mereka. Literasi media membuat anak berpikir kritis dan tidak begitu saja menerima pesan dari media seperti apa adanya.
Ada berbagai cara dan strategi yang dapat dilakukan untuk literasi media. Salah satu strategi yang digunakan adalah dengan menggunakan budaya dan kearifan lokal yang dimiliki oleh setiap masyarakat. Kellner dalam bukunya "Budaya Media: Cultural Studies, Identitas dan Politik, antara Modern dan Postmoder" mengatakan bahwa masyarakat sebetulnya dapat menolak pengaruh-pengaruh budaya media dengan menggunakan budaya yang mereka miliki. Pesan-pesan dominan yang disampaikan oleh media massa dan penciptaan pembacaan serta pemanfaatan pribadi terhadap budaya yang diproduksi secara masal oleh media dapat difilter dengan menggunakan budaya yang mereka miliki. Budaya yang dimiliki oleh masyarakat ini dapat digunakan sebagai sumber pemberdayaan diri mereka dan menciptakan makna identitas dan bentuk kehidupan mereka sendiri.

Menurut Kellner, salah satu cara yang dapat digunakan untuk menciptakan masyarakat yang cerdas dalam menggunakan media adalah dengan menggunakan budaya mereka sendiri. Dalam pandangan Kellner, budaya yang dihidupi oleh suatu masyarakat, dapat digunakan sebagai filter dalam menghadapi terpaan dari media massa yang nota bene menyampaikan pesan-pesan dengan berdasarkan pada budaya asing. Tidak bisa dipungkiri, selama ini media massa cenderung menyajikan tayangan dan menyampaikan informasi-informasi dengan latar belakang budaya asing. Pesan-pesan yang disampaikan oleh media merupakan konstruksi dari nilai-nilai budaya asing yang tidak jarang justru bertentangan dengan budaya yang kita miliki. Literasi 
media dengan berdasarkan pada budaya dan kearifan lokal yang dimiliki masyarakat kita, akan membuat generasi muda kita mengerti dan mememahami budaya dan kearifan lokal yang diturunkan oleh nenek moyang mereka. Di sisi yang lain, kearifan lokal yang dimiliki oleh suatu masyarakat, akan menjadi tameng dalam menghadapi terpaan televisi.

Kearifan lokal yang merupakan manifestasi dari ajaran-ajaran budaya yang dihidupi oleh suatu masyarakat lokal, dapat digunakan sebagai filter untuk menyerap dan mengolah kebudayaan asing sesuai watak dan kemampuan sendiri, termasuk budaya-budaya asing yang terpublikasi ke masyarakat melalui media massa. Nilai-nilai budaya serta kearifan lokal yang dimiliki oleh masyarakat dapat digunakan sebagai dasar pada saat menginterpretasikan pengalaman yang mereka peroleh dari media massa, sehingga tingkah laku sosial yang terbentuk merupakan tingkah laku sosial yang sesuai dengan budaya masyarakat itu bukan tingkah laku sosial yang berdasarkan budaya media.

Mengacu dari pendapat Kellner, kearifan lokal masyarakat Salatiga juga dapat digunakan sebagai filter dalam menghadapi terpaan televisi. Hanya saja, penerapan kearifan lokal sebagai filter dalam menghadapi terpaan televisi bukan suatu hal yang mudah. Mengingat dalam era globalisasi pada saat ini, banyak generasi muda yang tidak lagi mengerti, memahami dan menghidupi kearifan lokal dari budaya yang mereka miliki. Budaya luar yang masuk melalui media massa lebih banyak mempengaruhi hidupnya dibandingkan dengan budaya dan kearifan lokal yang mereka miliki. Sekalipun banyak generasi muda yang tidak memahami tentang budaya dan kearifan lokal masyarakat Salatiga, tetapi kearifan lokal dan budaya masyarakat Salatiga masih diterapkan dalam kehidupan sehari-hari. Hal ini dapat kita lihat dengan jelas dalam kehidupan masyarakat Salatiga dalam setiap harinya.

Sebagai kota kecil yang terletak di di lereng gunung Merbabu, Salatiga memiliki kearifan lokal yang sangat agung dan dihidupi oleh masyarakat Salatiga dalam kehidupan sehari-hari. Letak kota Salatiga yang berada di jalur regional Jawa Tengah yang menghubungkan kota Semarang, Yogyakarta dan Solo, membuat budaya yang dimiliki oleh masyarakat Salatiga sangat dipegaruhi oleh budaya yang bertumbuh di ketiga kota ini. Hal ini seperti yang dikatakan oleh Pak Amrih dalam wawacara mendalam pada tanggal 19 Juli 2017 yang mengatakan, "Budaya Salatiga merupakan akulturasi dari beberapa budaya yang ada, khususnya dari budaya Solo dan Yogyakarta". Budaya Solo dan budaya Yogyakarta ini menjadi dasar dari budaya yang berkembang di Salatiga.

Posisi kota Salatiga yang lebih dekat dengan kota Solo dibandingkan dengan kota Yogyakarta, membawa pengaruh yang sangat besar dalam perkembangan budaya Salatiga. Pada perkembangannya, budaya Salatiga sangat dipengaruhi oleh budaya Solo. Hal ini seperti yang dikatakan oleh Bapak Jarwadi, kepala dinas Kebudayaan Salatiga dalam wawancara mendalam yang dilalukan pada tanggal 21 Juli 2017, bahwa budaya masyarakat Salatiga cenderung mengikut budaya Solo, dengan toleransi dan gotong royong sebagai kearifan Lokal yang mereka miliki. Pak Amrih, 
budayawan yang ada di Salatiga mengatakan, "Pengaruh pangeran Samber Nyowo sangat kuat dalam budaya Salatiga. Pangeran Samber Nyowo memberikan ajaran tentang semangat perjuangan dan falsafah hidup mengenai kemandirian, kebebasan, gotong royong dan kebersamaan" (Pak Amrid, wawancara 21 Juli 2017).

Pada buku "Pangeran Sambernyowo: ringkasan Sejarah Perjuangan" (2008), Pangeran Sambernyowo yang terkenal dengan nama Raden mas Said memiliki prinsip dengan selogan juangnya “Tiji-Tibeh", yang memiliki makna mati siji mati kabeh dan mukti siji mukti kabeh (Satu meninggal, maka yang lain akan meninggal. Kalau yang satu bahagia, maka yang lain juga akan bahagia, sejahtera satu maka sejahtera semua). Prinsip ini yang membuat rakyat menjadi satu dalam kata dan perbuatan, maju dalam langkah dan derap yang serasi, mereka merupakan keluarga besar yang bagaikan kata pepatah "serumpun bagai serai, seliang bagai tebu”, memiliki makna, bersatu hati dalam segala hal (Yayasan Mangadeg, 1988: 21). Dalam perkembangannya, prinsip ini menjadi dasar hidup masyarakat Salatiga yang diterapkan dalam bentuk kebersamaan, saling menghargai dan toleransi. Prinsipprinsip ini tetap dihidupi dan diterapkan dalam kehidupan sehari-hari, yang dapat kita lihat dan amati sampai saat ini. Semangat kebersamaan, saling menghargai dan toleransi dapat kita lihat dari budaya yang berkembang di beberapa daerah yang ada di kota Salatiga dalam bentuk Saparan, maupun dalam ritual keagaman yang terjadi ditengah-tengah masyarakat Salatiga. Sikap saling menghargai dan membantu ketika umat yang satu melakukan ritual keagamaan ketika memperingati hari besar keagamaan mereka, menjadi bukti nyata kearifan lokal masyarakat salatiga dalam bentuk toleransi yang masih dijunjung sangat tinggi. Makanya tidak heran kalau dalam beberapa tahun terakhir ini kota Salatiga mendapat predikat sebagai kota paling toleran nomor dua di Indonesia.

Terkait dengan literasi media, budaya yang dimiliki oleh masyarakat Salatiga ini juga dapat digunakan sebagai filter dari pengaruh-pengaruh yang diberikan oleh media massa, maupun dari budaya-budaya yang disampaikan oleh media. Perkembangan teknologi yang sangat cepat dan pesat, membuat setiap kita tidak bisa menghindari dari teknologi dan dari pengaruh pesan yang disampaikan oleh teknologi tersebut. Rasanya menjadi hal yang sangat mustahil kalau untuk menghindari pengaruh dari teknologi dan dari pesan yang disampaikan, kemudian setiap individu berusaha tidak menggunakan teknologi tersebut. Artinya, kita tidak bisa menentang faktor eksternal untuk menghindari pengaruh media. Hal yang bisa kita lakukan adalah memperkuat faktor internal dalam diri kita, sebagai usaha memperkuat fondasi dalam menghadapi terpaan media. Salah satunya adalah dengan menggunakan kearifan lokal yang kita miliki.

Kearifan lokal masyarakat Salatiga dalam bentuk kebersamaan, gotong royong, saling menghargai dan toleransi dapat digunakan sebagai dasar dalam melakukan literasi media. Maksudnya, ajaran untuk membangun hidup secara bersama-sama, saling menghargai dan toleransi, dapat digunakan sebagai dasar hidup bagi setiap orang yang ada di Salatiga ketika 
mendapat terpaan dari media massa. Ketika masyarakat Salatiga (termasuk anak-anak Sekolah Dasar) mengerti dan menghidupi prinsip hidup kebersamaan, gotong royong, saling menghargai dan menghormati, maka dasar hidup ini dapat digunakan sebagai tameng untuk menentukan mana ajaran-ajaran dari televisi yang dapat dikonsumsi dan mana yang tidak. Pesan-pesan dari televisi mana saja yang sesuai dengan prinsip hidup yang mereka miliki, dan mana yang tidak. Di sisi lain, kearifan lokal masyarakat Salatiga ini dapat dikemas dalam bentuk media pembelajaran, sebagai strategi literasi media.

Literasi media yang dilakukan untuk anakanak Sekolah Dasar yang ada di Salatiga adalah model literasi media dengan berbasiskan pada toleransi, kebersamaan, saling menghargai dan gotong royong yang merupakan kearifan lokal masyarakat Salatiga. Kearifan lokal ini menjadi dasar ajaran dalam menyampaikan penyadaran tentang penggunaan media televisi secara cerdas.

Ada beberapa strategi yang dapat digunakan untuk melakukan literasi media untuk anak-anak Sekolah Dasar yang ada di Salatiga. Berdasarkan wawancara dengan beberapa guru dan kepala Sekolah Dasar yang ada di Salatiga, ada tiga strategi yang dapat digunakan dalam melakukan literasi media. Bu Padmi, salah satu guru di Sekolah Dasar Negeri 2 Salatiga, mengatakan,

"Guru tidak boleh berhenti untuk mengingatkan secara lisan supaya anak-anak tidak terlalu sering menonton televisi. Mengingatkannya bisa di dalam kelas waktu pelajaran maupun pada saat istirahat dengan cara menasehati anak" $(\mathrm{Bu}$ Padmi, wawancara 23 April 2017).

$\mathrm{Bu}$ Bangun, Kepala Sekolah di Sekolah Dasar Negeri 9 mengatakan,
"Supaya anak-anak mempunyai pemahaman dan kesadaran dalam menggunakan televisi, perlu ada edukasi di kelas. Edukasi bisa dilakukan dengan menggunakan video maupun dengan memberikan contoh-contoh yang ada. Selain edukasi kepada siswa di kelas, orang tua juga perlu diberikan pemahaman tentang penggunaan televisi secara benar" (Bu Bangun, wawancara 16 Mei 2017).

Pak Amrih, guru Sekolah Dasar Laboratorium UKSW serta budayawan salatiga mengatakan,

"Untuk mengingatkan dan menyadarkan anakanak dalam menggunakan televisi, perlu ada media yang digunakan. Misalnya dalam bentuk buku cerita komik untuk mengingatkan anakanak supaya menonton televisi secara benar" (Pak Amrih, wawancara 2 Juni 2017).

Berdasarkan hasil wawancara ini, ada tiga strategi yang dapat digunakan untuk melakukan literasi media kepada anak-anak, yaitu pertama, Melalui komunikasi secara lisan dan informal untuk mengingatan dan melakukan pendampingan. Kedua, melakukan edukasi kepada orang tua dan siswa secara tatap muka maupun dengan menggunakan media interaktif. Ketiga, dengan menggunakan media pembelajaran seperti menggunakan buku cerita, komik maupun dengan menggunakan media interaktif.

Berdasarkan pemetaan kearifan lokal masyarakat Salatiga yang dapat digunakan sebagai filter dalam menghadapi terpaan media, dan berdasarkan pemetaan strategi literasi media dari guru-guru dan dari kepala sekolah, maka dapat dibuat model literasi media. Mengacu dari pendapat Potter (2004: 33), Model literasi media menekankan empat faktor utama. Faktor yang pertama adalah struktur pengetahuan. Struktur pengetahuan ini nanti akan bekerjasama dengan faktor kedua, yaitu lokus pribadi. Pada lokus pribadi inilah keputusan tentang pemrosesan informasi itu terjadi. Faktor ketiga adalah kompetensi dan 
keterampilan seseorang, yang merupakan alat pengolah informasi. Faktor keempat adalah arus tugas pengolahan informasi. Keempat faktor tersebut bekerja sama secara interaktif dalam sebuah sistem.

Dibutuhkan struktur pengetahuan yang kuat yang didasari dengan lima komponen untuk membangun dasar dari literasi media. Kelima komponen tersebut adalah efek media, isi media, industri media, real world dan self. Komponen-komponen tersebut menjadi dasar bagaimana orang akan memahami tentang proses pengolahan informasi dan membuat mereka menjadi lebih mampu membuat keputusan yang lebih baik ketika mencari informasi, bekerja dengan informasi itu, dan memberikan makna terhadap informasi itu sehingga bermanfaat untuk kehidupan mereka. Berdasarkan pemahaman yang diberikan oleh Potter ini, maka model literasi media dengan menggunakan media interaktif dalam konsep kearifan lokal masyarakat Salatiga seperti flowchard (Gambar 2.).

Literasi media dengan berdasarkan pada kearifan lokal masyarakat Salatiga dapat dilakukan dengan dua cara, yaitu melalui komunikasi antar personal secara informal, dan melalui edukasi dengan menggunakan media interaktif, khususnya dengan menggunakan game. Model literasi melalui komunikasi antar personal dapat dilakukan oleh guru-guru dengan cara memberikan nasihat dan terus mengingatkan kepada siswa-siswi tentang dampak dari tayangan televisi. Kearifan lokal masyarakat Salatiga digunakan sebagai dasar ketika guru memberikan nasihat kepada muridmuridnya melalui komunikasi antar personal yang dilakukan secara informal.

Edukasi dilakukan dengan menggunakan media interaktif, khususnya dengan menggunakan game. Melalui pesan-pesan kearifan lokal yang disampaikan dengan menggunakan game ini, maka akan muncul : pertama, efek dari media (khususnya televisi) yang sesuai dengan setting yang ditampilkan dari game tersebut. Melalui game ini, efek yang muncul adalah anak-anak dapat mengakses televisi, dapat memilih pesan-pesan yang disampaikan oleh televisi, dapat menganalisa pesan yang disampaikan oleh televisi serta bijak dalam

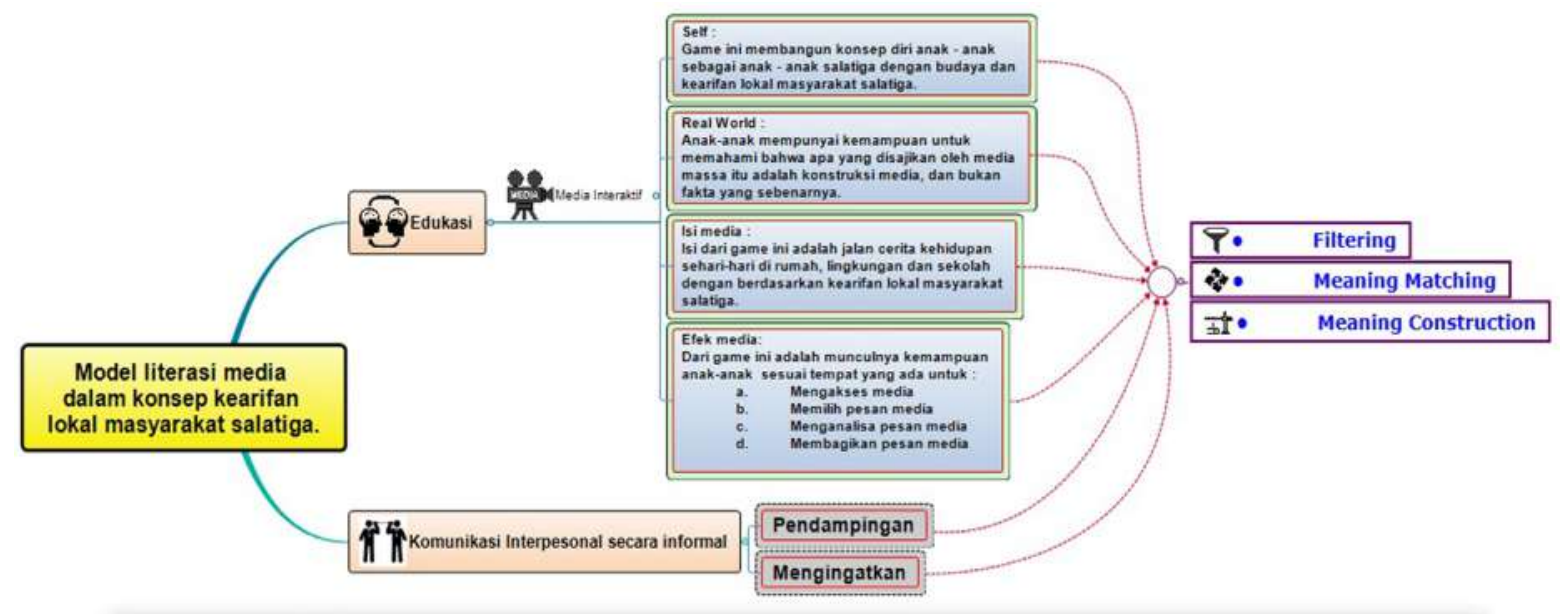

Gambar 2. Model Literasi Media dengan menggunakan multimedia interaktif berbasis kearifan lokal masyarakat Salatiga.

(Sumber : Data Peneliti 2017) 
menyebarkan pesan-pesan yang dia dapat dari televisi.

Kedua, isi media. Melalui game ini, anakanak akan dapat mengerti, memahami dan yang akhirnya akan menghidupi kearifan lokal masyarakat Salatiga yang diajarkan melalui game tersebut. Ketiga, melalui game ini, anakanak akan paham tentang realita dunia yang sebenarnya, bukan berdasarkan dari konstruksi yang dibangun oleh media. Keempat, game ini akan membangun konsep diri anak-anak, bahwa mereka adalah anak-anak Salatiga dengan identitas diri sebagai orang Salatiga.

Model literasi dengan menggunakan edukasi ini dilakukan dengan menggunakan multimedia, khususnya dengan menggunakan game. Literasi media dilakukan dengan menggunakan game edukasi dalam bentuk cerita kehidupan sehari-hari. Pada game ini seorang anak memainkan salah satu peran di dalam game itu. Game dibuat dengan setting Salatiga. Game disajikan dengan menampilkan tokoh-tokoh sebagai gambaran anak-anak Salatiga. Nama tokoh-tokoh utama adalah Welas dan Asih. Welas dan Asih merupakan nama dengan menggunakan bahasa Jawa yang memiliki arti belas kasihan dan memiliki kasih. kota Salatiga dan dengan latar belakang budaya

Belas kasihan dan kasih merupakan aplikasi dari kearifan lokal masyarakat Salatiga, yaitu toleransi, kebersamaan, saling menghargai dan menghormati. Tokoh Welas dan Asih seperti pada Gambar 3. dan Gambar 4.

Melalui edukasi dan komunikasi antar personal yang dilakukan secara informal, maka anak akan dapat menyaring semua pesan yang dia terima dari televisi. Setelah anak-anak dapat menyaring, maka kemudian mereka dapat memberikan makna secara tepat berdasarkan potongan-potongan pesan yang mereka dapat dari televisi. Tahapan yang terakhir adalah anak-anak memiliki kemampuan untuk mengkonstruksi pesan secara tepat, berdasarkan dari pesa-pesan yang mereka terima dari televisi.

\section{Simpulan}

Dari hasil analisis dan pembahasan di atas, dapat disimpulkan beberapa hal sebagai berikut, (1) Budaya Masyarakat Salatiga sangat dipengaruhi oleh budaya masyarakat Solo, Yogyakarta dan Semarang. Pada perkembangannya budaya Salatiga sangat dipengaruhi oleh budaya masyarakat Solo dengan berdasarkan pada ajaran Pangeran Samber Nyowo. Ajaran Pangeran Samber Nyowo inilah yang akhirnya menjadi dasar

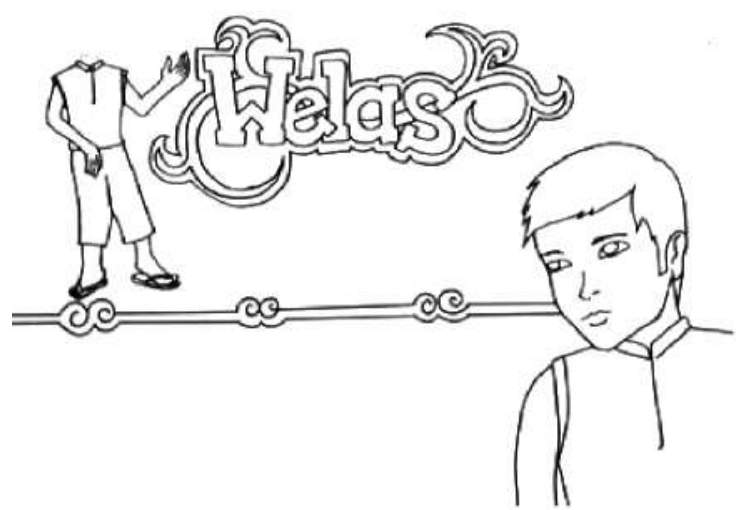

Gambar 3. Tokoh Welas

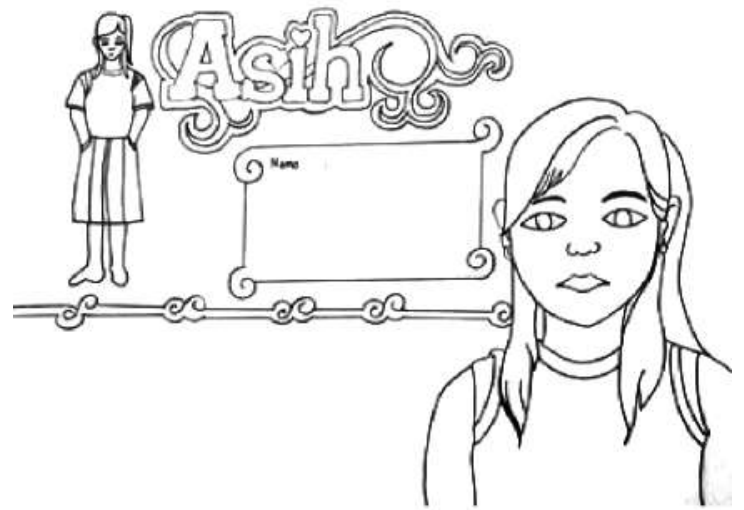

Gambar 4. Tokoh Asih

(Sumber : Data Peneliti 2017) 
kearifan lokal masyarakat Salatiga; (2) Kearifan lokal masyarakat Salatiga yang dapat digunakan sebagai dasar literasi media adalah prinsip hidup kebersamaan, saling menghargai, gotong royong dan toleransi; (3) Literasi media dengan berdasarkan pada kearifan lokal masyarakat Salatiga dilakukan dengan dua cara, yaitu melalui komunikasi antar personal secara informal, dan melalui edukasi dengan menggunakan media interaktif, khususnya dengan menggunakan game. Model literasi melalui komunikasi antar personal dapat dilakukan oleh guru-guru dengan cara memberikan nasihat dan terus mengingatkan kepada siswa-siswi tentang dampak dari tayangan televisi. Edukasi dilakukan dengan menggunakan media interaktif, khususnya dengan menggunakan game.

Budaya dan kearifan lokal yang dimiliki oleh suatu masyarakat dapat digali dan dipetakan sebagai model dalam menghadapi terpaan media. Ini menjadi pekerjaan rumah buat kita semua. Di satu sisi, gerakan ini akan membantu melestarikan budaya yang dimiliki oleh masyarakat kita, di sisi yang lain, budaya dan kearifan lokal yang dimiliki oleh suatu masyarakat dapat digunakan sebagai filter dalam menghadapi terpaan media, khususnya televisi.

\section{Daftar Pustaka:}

Birowo, Mario Antonius dan Rini Darmastuti. (2015). Strategi Literasi Media pada Remaja Yogyakarta dengan Berbasis Kearifan Lokal Masyarakat Yogyakarta. Laporan Penelitian. Yogyakarta : Universitas Atma Jaya Yogyakarta

Considine, David. The Journal of Media Literacy, Volume 41, Number 2.
Douglas, K. (2010). Budaya Media : Cultural Studies, Identitas, dan Politik : Antara Modern dan Posmodern. Yogyakarta: Jalasutra.

Littlejohn,Stephen W. (2001). Theories of Human Communication Fifth Edition. New York: Wadsworth Publishing Company

Potter, W. J. (1998). Media Literacy. Thousand : SAGE Publications . (2004). Theory of Media Literacy : A Cognitive Approach. California: Sage Publications. (2008). Media Literacy (4th ed.). Thousand Oaks: Sage Publications Inc.

Purnomo, Jusuf Tjahjo dan Rini Darmastuti. (2016). Model Literasi Media dalam Konsep Kearifan Lokal Masyarakat Samin. Laporan Penelitian Hibah Bersaing. Salatiga : Universitas Kristen Satya Wacana.

Tim Teknis Sejarah Pejuangan Pangeran Sambernyowo. (1988). Pangeran Sambernyowo : ringkasan Sejarah Perjuangan. 1988. Surakarta : Yayasan Mangadeg Surakarta.

\section{Internet :}

Armando, Nina M. (2010). Menjadikan Media sebagai Sumber Belajar. https://sutamto. wordpress.com/2010/11/06/menjadikanmedia-sebagai-sumber-belajar/, diakses 20 Oktober 2017.

Nielsen: Konsumsi Media Tren Baru di Kalangan Pengguna Internet di Indonesia. http://www.nielsen.com/id/en/pressroom/2017/Tren-Baru-di-KalanganPengguna-Internet-di-Indonesia.html, diakses 20 Nopember 2017.

Nielsen: Komsumsi Media Lebih Tinggi di Luar Jawa (2014) diakses dari http:// www.nielsen.com/id/en/pressroom/2014/ nielsenkonsumsimedialebihtinggidiluarjawa.html, diakses 29 Mei 2016. 